\title{
Entry Denied: COVID-19, Race, Migration, and Global Health
}

\author{
Matiangai Sirleaf* \\ University of Maryland School of Law, Baltimore, MD, United States
}

This essay uses the novel coronavirus pandemic as an entry point to explore the intersections between race, migration, and global health. The pandemic is simultaneously reviving stereotypical colonial imaginations about disease directionality, but also challenging racialized hierarchies of diseases. This essay illuminates how the racialization of diseases is reflected in historic and ongoing United States' migration law and policy as well as the global health law regime. By demonstrating the close relationship between often separately treated areas, the essay clarifies underlying currents in global health and migration law and policy that stem from fears of the racialized other. Rendering these intersections visible creates avenues for rethinking and reshaping both theory and praxis toward anti-subordination efforts.

Keywords: global health, international law, critical race theory, migration law, COVID-19, immigration law, public health law, third world approaches to international law

\section{OPEN ACCESS}

Edited by:

Jaya Ramji-Nogales,

Temple University, United States

Reviewed by:

Angela Banks,

Arizona State University, United States

Ruqaiijah Yearbyr,

Saint Louis University, United States

*Correspondence:

Matiangai Sirleaf

msirleaf@law.umaryland.edu

Specialty section:

This article was submitted to

Refugees and Conflict.

a section of the journal

Frontiers in Human Dynamics

Received: 26 August 2020 Accepted: 11 November 2020 Published: 15 December 2020

Citation:

Sirleaf M (2020) Entry Denied: COVID-19, Race, Migration, and Global Health

Front. Hum. Dyn. 2:599157. doi: 10.3389/fhumd.2020.599157

\section{INTRODUCTION}

The coronavirus disease (COVID-19) ${ }^{1}$ has resurfaced outdated but persistent settler-colonial conventions that have mapped illness and disease on to racialized peoples and certain geographic regions. The President of the United States has sought to revitalize "Yellow Peril" with his xenophobic and racist references to the coronavirus disease that play on anxieties of the "alien" and their illnesses ${ }^{3}$. The President's incessant racist and inaccurate references to COVID-19 as the "Wuhan Virus," "Kung Flu," and "Chinse Virus"," harken to a long history of othering and denigrating Black, Indigenous and other people of color as infection-prone, afflicted with exotic sicknesses and generally unhealthy. For instance, when the bubonic plague hit San Francisco at the beginning of the twentieth century, Chinatown was forcibly quarantined ${ }^{5}$. Chinese residents, considered unclean by the authorities, could not go to work, and went hungry, as it was difficult to find food ${ }^{6}$.

\footnotetext{
${ }^{1}$ For further discussion see, for example, Coronavirus (COVID-19), CTRS. FOR DisEASE CONTROL \& PrEvention, https:// www.cdc.gov/coronavirus/2019-ncov/index.html (last visited August 7, 2020).

${ }^{2}$ In 1895, this term was defined as the belief in the danger to Western civilization held to arise from expansion of the power and influence of eastern Asian peoples. See Yellow Peril, MERRIAM-WEBSTER.COM DiCTiONARY, https://www.merriam-webster. com/dictionary/yellow\%20peril (last visited August 14, 2020).

${ }^{3}$ See, e.g., E. Tendayi Achiume, Special Rapporteur on Contemporary Forms of Racism, Racial Discrimination, Xenophobia, and Related Intolerance, States Should Take Action Against COVID-19-related Expressions of Xenophobia, Says UN Expert, U.N. Human Rights OfF. High Comm'R (Mar. 23, 2020), https://www.ohchr.org/EN/NewsEvents/Pages/DisplayNews. aspx?NewsID=25739\&LangID=E.

${ }^{4}$ David Nakamura, With 'Kung Flu,' Trump Sparks Backlash over Racist Language - and a Rallying Cry for Supporters, WASH. POST (June 24, 2020), https://www.washingtonpost.com/politics/with-kung-flu-trump-sparks-backlash-over-racistlanguage--and-a-rallying-cry-for-supporters/2020/06/24/485d151e-b620-11ea-aca5-ebb63d27e1ff_story.html.

${ }^{5}$ Charles McClain, Of Medicine, Race, and American Law: The Bubonic Plague Outbreak of 1900, 13 LAW \& Soc. INQUIRY $447,452(1988)$

${ }^{6}$ For further discussion, see generally NAYAN SHAH, CONTAGIOUS Divides: EPIDEMICS AND RACE IN SAN FRANCISCO'S CHinatown (2001).
} 
The association of people of color with various maladiesor what I have referred to as the "racialization of diseases" in other work-attaches racial meaning to ailments based on the racial groups that tend to be socially associated with a given illness ${ }^{7}$. The practice of racializing diseases is socially constructed as disease carrying microorganisms do not differentiate amongst their victims based on race, nationality, ethnicity, or other categories. While these microorganisms do not discriminate, societal actors do individually and systemically via direct and indirect action, which is exhibited by racialized health disparities and inequities ${ }^{8}$. The racialization of diseases is manifested in myriad areas of law and policy, especially the areas of migration and global health. In this essay, I clarify how the racialization of diseases is reflected in historic and ongoing United States' migration law and policy as well as the global health law regime.

\section{RACIALIZATION OF DISEASES AND U.S. MIGRATION LAW AND POLICY}

The othering of Black, Indigenous, and other people of color as diseased in the United States has a long history. Black people in the United States were considered a "notoriously syphilissoaked race" while when White people contracted diseases like polio, it was due to their complex and delicate bodies, which made them more susceptible ${ }^{9}$. This racialization of diseases is similarly reflected in United States migration law and policy. For example, Chinese migrants were subject to invasive and often humiliating medical inspections due to the presumption that they were disease ridden, which Europeans arriving through Ellis Island were not subjected to ${ }^{10}$. Further, the Chinese Exclusion Act, an immigration law passed in 1882 in the United States ${ }^{11}$, prevented Chinese laborers from immigrating in part based on racialized biases and prejudices that Chinese people were somehow more prone to have and transmit cholera and smallpox ${ }^{12}$. A century afterwards, the government of the United States established a detention center in Guantanamo

\footnotetext{
${ }^{7}$ See Matiangai Sirleaf, Racial Valuation of Diseases, 68 UCLA L. REV. (forthcoming 2020) (manuscript on file with author).

${ }^{8} I d$. The public health literature has also recognized such racial inequality as a social determinant of health. See, e.g., Asad L. Asad and Matthew Clair, Racialized Legal Status as a Social Determinant of Health, 199 SoC. SCI. \& MED. 19 (2018) (discussing how racialized legal status is a social position with fundamental health effects); Heide Castañeda et al., Immigration as a Social Determinant of Health, 36 ANn. Rev. Pub. Health 375 (2015) (applying "a broad social determinants lens to understand[ing]immigrants' experiences and how related policies impact health"); Mary A. Gerend and Manacy Pai, Social Determinants of Black-White Disparities in Breast Cancer Mortality: A Review, 17 CAnCer Epidemiology, Biomarkers \& PREVENTION 2913 (2008) (using the social determinants of health disparities model to review disparities in mortality from breast cancer between White and Black women).

${ }^{9}$ James H. Jones, Bad Blood: The Tuskegee Syphilis Experiment 29 (1993) [hereinafter JONES, BAD BLOOD].

${ }^{10}$ SHAH, supra note 6, at 198.

${ }^{11}$ An Act to Execute Certain Treaty Stipulations Relating to the Chinese, May 6, 1882, Enrolled Acts and Resolutions of Congress, 1789-1996; General Records of the United States Government; Record Group 11; National Archives, https://www. ourdocuments.gov/doc.php?flash=false\&doc $=47$ (last visited August 17, 2020).

${ }^{12}$ Salonee Bhaman et al., Histories: Public Health \& Xenophobic Racism, in ASIAN Am. Feminist Antibodies 5 (March 2020).
}

Bay, Cuba from 1991 to 1993 and held 310 Haitians with HIV/AIDS notwithstanding their refugee and asylum rights ${ }^{13}$. Although every detainee had a credible basis for claiming political persecution, they were nonetheless uniformly prohibited from entering the United States to seek asylum ${ }^{14}$.

The intersections between racialization, migration, and disease have continued to the present day. Most recently, the United States Department of Homeland Security and the Executive Office for Immigration Review put forward a rule proposal for public comment in July of $2020^{15}$. The rule if adopted, would enable officials to rely on "emergency public health concerns based on communicable disease due to potential international threats from the spread of pandemics when making a determination as to whether" there are reasonable grounds for considering an individual as a "danger to the security of the United States' and, thus, ineligible to be granted asylum or the protection of withholding of removal in the United States ${ }^{16 "}$. As aptly observed by Jaya Ramji-Nogales, the securitization of public health concerns can easily be "manipulated to exclude asylum seekers on grounds that are not explicitly racial but map conveniently onto racial categories ${ }^{17}$ ". Notably, at the time of publication, the United States sits at the top of the COVID19 pandemic statistics with the national death toll well above 269,000 and with over thirteen million cases ${ }^{18}$. The incongruency of the United States leading the world in the number of cases globally of COVID-19 as well as with the number of deaths per country due to the disease ${ }^{19}$, yet seeking to place blame on racialized others and barring them from entry to the country was apparently not relevant to the administration.

The almost reflexive turn for some to treat migrants as "dangerous others ${ }^{20}$ " and harbingers of disease has materialized with the COVID-19 pandemic in the United States. A paradigmatic example of this occurred when Florida governor Ron DeSantis blamed largely Latinx migrant workers for the state's rise in COVID-19 cases in a press conference in June of $2020^{21}$. The governor racialized COVID-19 and scapegoated migrant workers, which obfuscated that fields had long since been cleared for harvest with many workers returning to

\footnotetext{
${ }^{13}$ See Michael J. Ratner, How We Closed the Guantanamo HIV Camp: The Intersection of Politics and Litigation, 11 HARV. HUM. RTS. J. 187 (1998).

${ }^{14}$ See Harold Koh. The "Haiti Paradigm" in United States Human Rights Policy, 103 YALE L.J. 2397 (1994).

${ }^{15}$ Security Bars and Processing, 85 Fed. Reg. 41,201 (proposed July 9, 2020) (to be codified at 8 C.F.R. pt. 208).

${ }^{16} I d$. at 41,201 (if adopted this rule would amend the Immigration and Nationality Act sections 208 and 241 and other regulations to allow for removal on the proposed grounds).

${ }^{17}$ Jaya Ramji-Nogales. Dispatches from a Racialized Border: The Invisible Threat, JUST SEC. (July 27, 2020), https://www.justsecurity.org/71678/dispatches-from-aracialized-border-the-invisible-threat/.

${ }^{18}$ See COVID-19 Dashboard by the Center for Systems Science and Engineering (CSSE), John Hopkins University \& Medicine Coronavirus Resource CENTER, https://coronavirus.jhu.edu/map.html (last visited December 1, 2020). ${ }^{19} \mathrm{Id}$.

${ }^{20}$ Gideon Lasco, Medical Populism and the COVID-19 Pandemic, 15 GLOBAL PUB. HeALth 1417, 1419 (2020).

${ }^{21}$ Daniel Chang and Ben Conarck, DeSantis Attributes COVID Surge to Farmworkers. Aid Groups Say Testing Help Came Late, Miami Herald (June 19, 2020), https://www.miamiherald.com/news/coronavirus/article243614522.html.
} 
their communities. Further, his racist and xenophobic remarks attempted to deflect attention away from the governor's decision to keep busy spring break beaches open, his initial resistance to issuing a lock-down order ${ }^{22}$, and other governmental and societal failures to limit transmission of COVID-19. In fact, this harkens back to longstanding colonial and racial logics that defined the emergence of the global health regime.

\section{WHITE HEALTH AS GLOBAL HEALTH}

The early efforts at global health cooperation by European powers were premised on containing racialized threats of disease contagion from colonized peoples. For example, the adoption of the 1897 Sanitary Convention followed an outbreak of the plague in India ${ }^{23}$, and some Europeans feared that their Muslim subjects in colonial territories might become infected by Indian pilgrims and bring the plague back with them ${ }^{24}$. Consequently, the International Sanitary Convention of 1897 prioritized the plague as a disease warranting international attention $^{25}$. Imperial powers increasingly focused on creating an international system of quarantine regulations to protect the colonial metropole ${ }^{26}$. This resulted in the enactment of 13 international treaties adopting health control measures in the first half of the twentieth century ${ }^{27}$.

The health and well-being of European peoples was of particular concern following World War I, given the influenza pandemic, which claimed an estimated 50-100 million persons between 1918 and $1919^{28}$. Public health officials at that time deemed it impractical to impose international quarantine measures to address the influenza pandemic ${ }^{29}$. Accordingly, influenza was not included in the list of internationally notifiable diseases under the Sanitary Convention of $1926^{30}$. Instead, the 1926 Convention modified the 1912 Convention and required

\footnotetext{
${ }^{22}$ See, e.g., State of Florida, Office of the Governor, Exec. Order No. 20-91, Essential Services and Activities During COVID-19 Emergency (April 1, 2020). https:// www.flgov.com/wp-content/uploads/orders/2020/EO_20-91-compressed.pdf.

${ }^{23}$ See Norman Howard-Jones, World Health Org. [WHO]. The Scientific Background of the International Sanitary Conferences 1851-1938, 1 HIST. INT'L Pub. Health 1, 78 (1975) [hereinafter Howard-Jones, WHO].

${ }^{24} I d$.

${ }^{25}$ See International Sanitary Convention of 1897 (March 19, 1897). See also Howard-Jones, WHO, supra note 23, at 78-80 (1975); Wallace S. Jones, Italy. International Sanitary Conference, 12 PUB. HEALTH REPS. 452 (1897).

${ }^{26}$ See Howard-Jones, WHO, supra note 23, at 11 (discussing how Western powers wanted to determine how restrictive quarantine regulations needed to be to continue the expansion of imperial trade without exposing their populations on the mainland to health risks from colonial territories).

${ }^{27}$ See generally WHO, Proceedings of the Special Committee and of the Fourth World Health Assembly on WHO Regulations No. 2, 1 (1952) (discussing the background to the International Sanitary Conferences and any resulting treaties from 1851 to 1938$)$.

${ }^{28}$ See Howard-Jones, WHO, supra note 23, at 93. See also David Morens and Anthony Fauci. The 1918 Influenza Pandemic: Insights for the 21st Century, 195 J. INFECTIOUS DisEASES 1018 (2007) (noting that the 1918-1919 H1N1 influenza pandemic was one of the deadliest events in recorded human history).

${ }^{29}$ See P.G. Stock. The International Sanitary Convention of 1944, 38 PROCEEDINGS ROYAL SOC'Y MED. 309, 311 (noting that the Convention did not include a proposal to include influenza among the diseases covered).

${ }^{30}$ See generally International Sanitary Convention of 1926 arts. 1 and 8 (June 21, 1926). For further discussion see Howard-Jones, WHO, supra note 23, at 97.
}

international notification for the first confirmed cases of cholera, plague, yellow fever, as well as small pox and typhus ${ }^{31}$. At the time, there were millions of cases of typhus in Poland and the Soviet Union following $\mathrm{WWI}^{32}$.

Western powers already deemed yellow fever, the plague, and cholera as significant by then, as the very first International Sanitary Conference was convened to address the danger that these diseases posed to Europe ${ }^{33}$. Of the three, cholera sparked the most fear because it had reached Russia from India ${ }^{34}$. The entirety of the 1892 Sanitary Convention accordingly only pertains to cholera and the sanitary control of westbound shipping to European countries based on fears that the Suez Canal might be a conduit for the importation of cholera from India to Europe ${ }^{35}$. The Euro-centric focus of the early global health treaties is also exhibited in the 1903 Convention $^{36}$. White Europeans initially regarded the control of yellow fever as a minor concern limited to the Americas ${ }^{37}$. Thus, of the 1903s Convention's 184 articles, only one relates to yellow fever, while the rest of the provisions concern the plague and cholera ${ }^{38}$.

The above analysis indicates that the expansion of the list of diseases that deserved international recognition under global health law coincided with the salience given to responding to these diseases in Western capitals. It was not as if diseases prioritized by the Sanitary Conventions were the only diseases afflicting populations globally. Yet, it was not until the 1944 modification of the International Sanitary Convention that the global health regime began requiring state parties to send epidemiological information for diseases not prioritized by White majoritarian interests in Western capitals ${ }^{39}$. An assessment of the emergence of the global health regime that simplifies things down to a matter of Western states pursuing their national interests obscures underlying issues as the early global health treaties did not take place in a vacuum. European colonial powers formulated the nascent global health regime to perfect the colonial project.

\section{RACIALIZED BORDERS AND THE CREATION OF THE NATION-STATE}

The global health regime's emergence was coterminous with the creation of the nation-state and the erection of "racial

\footnotetext{
${ }^{31}$ International Sanitary Convention of 1926, supra note 30, arts. 1 and 8.

${ }^{32}$ Howard-Jones, WHO, supra note 23 , at 93.

${ }^{33}$ For further discussion see generally, Valeska Huber. The Unification of the Globe by Disease? The International Sanitary Conferences on Cholera, 1851-1894, 49 HisT. J. 453-76 (2006).

${ }^{34}$ Howard-Jones, WHO, supra note 23 , at 9.

${ }^{35}$ See International Sanitary Convention of 1892 art. 4 (Jan. 9, 1892) (noting measures to prevent cholera). See also Howard-Jones, WHO, supra note 24, at 65.

${ }^{36}$ See International Sanitary Convention of 1903 (December 3, 1903). See also Howard-Jones, WHO, supra note 23, at 85.

${ }^{37}$ Howard-Jones, WHO, supra note 23, at 85 .

${ }^{38}$ See International Sanitary Convention of 1903, supra note 36, at art. 182 (noting that interested countries are recommended to modify their sanitary regulations to bring them in line with current scientific findings on the mode of transmission of yellow fever, especially the role of mosquitoes as vehicles of germs of the disease). ${ }^{39} \mathrm{Cf}$. International Sanitary Convention of 1944, art. 5A with art. 5B (December 15, 1944) (modifying the International Sanitary Convention of 21 June 1926).
} 
borders ${ }^{40}$ " in many places. The foundation of the nationstate itself was influenced by the racialization process, which involves "the extension of racial meaning to a previously racially unclassified relationship, social practice or group ${ }^{41}$ ". As Europeans encountered different societies and peoples, they created race as a biological or natural occurrence and came up with a racial categorization system for the human species ${ }^{42}$. Racialized social systems constructed by White Europeans allocated different economic, political, social, and other rewards to groups along racial lines internally and external to the nation-state ${ }^{43}$.

The racialized construction of the nation-state was legitimated by scientific racism ${ }^{44}$, which then reified categories such as "Indians" and "Negroes." Scientific racism was used to justify, propose, and project scientific findings and theories, which facilitated and reinforced the enactment of racist social policies ${ }^{45}$. Scientific racism was intertwined with the "civilizing mission" of European imperial expansion and helped to facilitate the subjugation of Black, Indigenous, and other people of color. Racialized social systems then created vested interests in keeping or transforming the society's racial structure ${ }^{46}$ nationally and transnationally. Viewed in this way, the formation of nationstates in many ways was the result of drawing borders internally and externally of "we" vs. "them," "insider" vs. "outsider," and "foreigner" vs. "alien" at all levels of racialized societies.

\section{CREATION OF THE WORLD HEALTH ORGANIZATION}

Many of these nation-states would later draft and adopt the constitution of the World Health Organization (WHO) in $1946^{47}$. This new organization was to be committed to the principle that "the enjoyment of the highest attainable standard of health is one of the fundamental rights of every human being without distinction of race, religion, political belief, economic, or social condition ${ }^{48}$ ". The WHO was also founded on the premise that the health of all peoples is fundamental to the attainment of peace and security and is dependent

\footnotetext{
${ }^{40}$ For further discussion of this concept, see E. Tendayi Achiume, Racial Borders (manuscript on file with author).

${ }^{41}$ Michael Omi and Howard Winant, Racial Formation in the United STATES: From the 1960S TO THE 1990s, 64 (2d ed. 1994).

${ }^{42}$ See e.g., Matthew Clair and Jeffrey S. Denis, Sociology of Racism, 19 INT'L ENCYCLOPEDIA SOC. \& BEHAV. SCI. 857 (2015).

${ }^{43}$ Eduardo Bonilla-Silva, Rethinking Racism: Toward a Structural Interpretation, 62 AM. Soc. ReV. 465, 474 (1997).

${ }^{44}$ Scientific racism refers to the scientific and biomedical endeavor to support and explain variance between human groups as innate and involving a qualitative racial hierarchy. See generally ElAZAR BARKAn, THE Retreat of SCIENTIFIC RACISM: CHANGING CONCEPTS OF RACE IN BRITAIN AND THE UNITED STATES between the World Wars (1992); Saul Dubow, Scientific Racism in MODERn SOUTH AFrica (1995).

${ }^{45}$ See Rutledge M. Dennis. Social Darwinism, Scientific Racism, and the Metaphysics of Race, 64 J. NEGRO EDUC. 243 (1995).

${ }^{46}$ See Bonilla-Silva, supra note 43 , at 471 .

${ }^{47}$ See WHO Constitution art. 82, July 22, 1946, 14 U.N.T.S. 185 (entered into force April 7, 1948) [hereinafter WHO Constitution].

${ }^{48}$ Id. pmbl.
}

upon the fullest co-operation of individuals and states ${ }^{49}$. These foundational principles indicate that the privileging of White, colonial, European, and/or Western interests would presumably be less central, yet this has not proven to be the case in practice.

The basic premise of the global health regime remains the same, with an international system of state surveillance and notification for certain infectious disease ${ }^{50}$. The relevant treaty obligations stem from the International Health Regulations of 2005, which aims to "prevent, protect against, control and provide a public health response to the international spread of disease in ways that are commensurate with and restricted to public health risks, and which avoid unnecessary interference with international traffic and trade ${ }^{51}$." Under the regulations, the WHO can make wide-ranging temporary or standing recommendations concerning travel including: placing suspected "persons under public health observation;" implementing "quarantine or other health measures for suspect[ed] persons;" refusing "entry of suspect[ed] and affect[ed] persons;" refusing "entry of unaffected persons to affected areas;" and implementing "exit screening and/or restrictions on persons from affected areas;" amongst others ${ }^{52}$.

Significantly, member states gave the WHO the power to declare a Public Health Emergency of International Concern (PHEIC), "an extraordinary event, which is determined... (i) to constitute a public health risk to other States through the international spread of disease and (ii) to potentially require a coordinated international response ${ }^{53}$." The Regulations empower the Director General of the WHO's Secretariat, in conjunction with a committee of mostly medical experts, to declare a PHEIC ${ }^{54}$. The Regulations also require the Director General to consider the views of state parties, the advice of a committee, and scientific principles as well as other factors when issuing, modifying, or terminating temporary and standing recommendations ${ }^{55}$. None of the enumerated criteria to guide decision-making includes consideration of race or the race of the populations impacted by a given disease.

\section{RACIALIZATION OF DISEASES AND GLOBAL HEALTH LAW AND POLICY}

Instead, the racialization of diseases in global health law and practice is accomplished subtly and indirectly. Indeed, while the regulations set out the framework for recommendations and emergency decision-making, they do not determine when an emergency should be declared nor when recommendations should be put forward ${ }^{56}$. The broad discretion regarding when a given disease constitutes an international emergency and what recommendations to put forward allows for decision-making

\footnotetext{
${ }^{49} I d$.

${ }^{50}$ See generally WHO, InTERNATIONAL HEALTH REgulations, arts. 5-6 (2d ed. 2005) [hereinafter IHRs of 2005].

${ }^{51} \mathrm{Id}$. art. 2.

${ }^{52}$ Id. art. $18(1)$.

${ }^{53} I d$. art. 1 (defining a "public health emergency of international concern").

${ }^{54}$ Id. arts. $12-17,48-49$.

${ }^{55} \mathrm{Id}$. art. 17.

${ }^{56} I d$. art. 12 and 49.
} 
informed either explicitly or implicitly by the racialization of diseases. This was on vivid display during the 2014-2015 Ebola outbreak in West Africa. The Ebola epidemic resuscitated historical images of Black African bodies as uncontainable and disease-ridden. The WHO seized on the fact that someone with Ebola traveled on an international flight as an opportunity to revise its initial slow and flat-footed stance toward the disease ${ }^{57}$. Yet, the circumstance that triggered the WHO's declaration of a public health emergency of international concern-someone $e^{58}$ from Liberia who was infected with Ebola traveling to Nigeriacan hardly be viewed as the seminal event in the disease's trajectory that the organization purported it was ${ }^{59}$.

The epidemic was already international in nature and a PHEIC might have been declared earlier, if White health were more implicated. Certainly, Ebola had already traveled across borders in West Africa to upend things in three countries ${ }^{60}$. The possibility of the disease spreading via air travel was always present ${ }^{61}$. Confirmation of transmission via air travel, transformed Ebola from a "local" disease in "Africa," to one that potentially touched and concerned countries in the Global North. Thus, the comparatively trivial number of cases that occurred in Europe (three) and the United States (four) ${ }^{62}$ turned Ebola into a crisis calling for international action. Consequently, the 2014-2015 Ebola epidemic in West Africa was converted from an unfortunate situation in a "backward" region to a significant public health emergency of international concern.

The WHO's recommendations to address the 2014-2015 epidemic allowed for limited travel restrictions for all confirmed or suspected cases of Ebola ${ }^{63}$. Significantly, the WHO specifically advised against general bans on international travel ${ }^{64}$. The organization explained that a general travel ban would likely "cause economic hardship, and could consequently increase the uncontrolled migration of people from affected countries, raising the risk of international spread of Ebola ${ }^{65}$ ". In the first study aimed at assessing state compliance with the WHO's recommendations, of the 187 (95.4\%) of the 196 states parties included in the study, " $23.0 \%$ had imposed a ban on the entry of foreigners traveling from countries with widespread

\footnotetext{
${ }^{57}$ See J. Benton Heath, Global Emergency Power in the Age of Ebola, 57 HARV. INT'L L.J. 1, 29 (2016).

${ }^{58}$ See WHO, Ebola Outbreak in West Africa Declared a Public Health Emergency of International Concern, WHO Regional Office for Europe (2014), http://www. euro.who.int/en/health-topics/emergencies/ebola-outbreak-2014.

${ }^{59}$ See generally Factors that Contributed to Undetected Spread of the Ebola Virus and Impeded Rapid Containment, WHO (January, 2015). http://www.who.int/csr/ disease/ebola/one-year-report/factors/en/.

${ }^{60}$ Heath, supra note 57 , at 30.

${ }^{61} \mathrm{Id}$.

${ }^{62}$ See 2014-2016 Ebola Outbreak in West Africa, CTRS. FOR DisEASE CONTROL \& PREVENTION, https://www.cdc.gov/vhf/ebola/history/2014-2016-outbreak/index. html.

${ }^{63}$ Press Release, WHO, Statement on the 1st meeting of the IHR Emergency Committee on the 2014 Ebola Outbreak in West Africa (August 8, 2014), http:// www.who.int/mediacentre/news/statements/2014/ebola-20140808/en/.

${ }^{64}$ WHO, Statement on the 3rd meeting of the IHR Emergency Committee regarding the 2014 Ebola Outbreak in West Africa (2014), http://www.who.int/ mediacentre/news/statements/2014/ebola-3rd-ihr-meeting/en/.

${ }^{65} I d$.
}

transmission of Ebola ${ }^{66 "}$. The results also indicated that " 58 (31.0\%) of the States Parties... had exceeded or disregarded the 2005 IHR's international travel recommendations ${ }^{67}$ ". Further, the study revealed that "entry of foreigners who had departed from a country with widespread transmission of Ebola was prohibited in $43(23.0 \%)$ and another 15 (8.0\%) of the States Parties had applied exclusions or substantial restrictions to such travelers ${ }^{68}$ ".

Under the Regulations, state parties are permitted to implement health measures in response to a PHEIC that "achieve[s] the same or greater level of health protection than WHO recommendations" as long as those "measures shall not be more restrictive of international traffic and not more invasive or intrusive to persons than reasonably available alternatives that would achieve the appropriate level of health protection ${ }^{69}$ ". While additional health measures are allowed under the Regulations that significantly interfere with international travel, states that decide to adopt these measures are required to "provide to WHO the public health rationale and relevant scientific information for it $^{70}$ ". Further, the Regulations clarify that "significant interference generally means refusal of entry or departure of international travelers... or their delay, for more than $24 \mathrm{~h}^{71}$ ". State parties that apply additional measures that significantly interfere, are within 3 months to undertake a review "taking into account the advice of $\mathrm{WHO}^{72}$ ". However, at one point during the Ebola epidemic in 2014-2015, Australia restricted the entry of "everyone who was not an Australian citizen or an Australian permanent resident ${ }^{73}$ ". The consequences of the lack of a robust monitoring mechanism for assessing when countries deviate from the WHO's recommendations allows significant room for countries to implement policies not based on any public health rationale ${ }^{74}$. Furthermore, the WHO's inability to impose sanctions on state parties in the event of non-compliance with its recommendations ${ }^{75}$ also means that potentially protective provisions that require state parties to implement and apply health measures "in a transparent and non-discriminatory manner," lacks much enforceability ${ }^{76}$. The WHO has remarked that perhaps "the best incentives for compliance are "peer pressure" and public knowledge" since "[s]tates do not want to

\footnotetext{
${ }^{66}$ Wendy Rhymer and Rick Speare, Countries' Response to WHO's Travel Recommendations Curing the 2013-2016 Ebola Outbreak, 95 BULL. WORLD HEALTH ORG. 10-17 (2017), https://www.who.int/bulletin/volumes/95/1/16$171579 / \mathrm{en} /$.

${ }^{67} I d$.

${ }^{68} \mathrm{Id}$.

${ }^{69}$ IHRs of 2005, supra note 50, art. 43(1)(a)(b).

${ }^{70} \mathrm{Id}$. art. 43(3). See also id. art. 43(5).

${ }^{71} I d$. art. $43(3)$.

${ }^{72}$ Id. art. 43(6).

${ }^{73}$ See Rhymer and Rick Speare, supra note 66.

${ }^{74}$ See id.

${ }^{75}$ See generally IHRs of 2005, supra note 50 (the Regulations do not include any enforcement mechanism per se for state parties that fail to comply with its provisions).

${ }^{76}$ Id. art. 42.
} 
be isolated ${ }^{77 "}$. Yet, more often than not it is the WHO that is the one isolated from state action.

Moreover, the Regulations' failure to engage with race obscures the role of racism and subordination in global health. Indeed, despite the long history of racializing diseases ${ }^{78}$, the IHRs of 2005 do not specifically refer to historic or ongoing racial discrimination in public health or medicine $\mathrm{f}^{79}$. The IHRs of 2005 rendering of race invisible is especially glaring in the provision requiring that all travelers are treated with "respect for their dignity, human rights, and fundamental freedoms," when implementing health measures. This provision explicitly calls for recognition of the "gender, sociocultural, ethnic, or religious concerns" of travelers, but does not mention race ${ }^{80}$.

The backgrounding of race under the current regime provides state parties with significant latitude to make choices influenced by the implicit or explicit racialization of diseases. For example, the weaknesses in the Regulations allow for decision-making informed by the racialization of diseases when countries formulate their emergency responses to disease outbreaks. The WHO declared COVID-19 a public health emergency of international concern on January 30, $2020^{81}$. The WHO consistently "advise[s] against the application of travel or trade restrictions to countries experiencing COVID19 outbreaks $^{82 "}$. Yet, by February 27, 2020, 38 countries reported taking additional health measures to the WHO "that significantly interfere with international traffic in relation to travel to and from China or other countries, ranging from denial of entry of passengers, visa restrictions, or quarantine for returning travelers ${ }^{83}$ ".

COVID-19 is the most recent instantiation of the racializing of diseases. For instance, a newspaper in France recently carried the headline "Yellow Alert" on its front page ${ }^{84}$. Additionally, the government of the United States' response to COVID-19 is emblematic of decision-making informed by the racialization of diseases. The administration initially primarily relied on general travel bans in its response to the spread of the novel coronavirus,

\footnotetext{
${ }^{77}$ WHO, Frequently ASKed Questions ABOUt THE INTERNATIONAL HeAlth Regulations (2005), https://www.who.int/ihr/about/FAQ2009.pdf? ua $=1$ (last visited August 16, 2020).

${ }^{78}$ See generally Sirleaf, Racial Valuation of Diseases, supra note 7.

${ }^{79}$ See generally IHRs of 2005, supra note 50.

${ }^{80} \mathrm{Id}$. art. 32.

${ }^{81}$ WHO, Statement on the second meeting of the International Health Regulations (2005) Emergency Committee regarding the outbreak of novel coronavirus (2019nCoV) (January 30, 2020), https://www.who.int/news-room/detail/30-01-2020statement-on-the-second-meeting-of-the-international-health-regulations(2005)-emergency-committee-regarding-the-outbreak-of-novel-coronavirus(2019-ncov).

${ }^{82}$ WHO, Updated WHO Recommendations for International Traffic in Relation to COVID-19 Outbreak, (February 29, 2020), https://www.who.int/news-room/ articles-detail/updated-who-recommendations-for-international-traffic-inrelation-to-covid-19-outbreak [hereinafter WHO, COVID-19 Travel Advice]. ${ }^{83}$ Id.

${ }^{84}$ Motoko Rich, As Coronavirus Spreads, So Does Anti-Chinese Sentiment, N.Y. TIMES (January 30, 2020), https://www.nytimes.com/2020/01/30/world/ asia/coronavirus-chinese-racism.html [citing Coronavirus Chinois: Alerte Juane, COURRIER PiCARD 24 (January 26, 2020)].
}

by first banning foreign nationals who had traveled to China in the last 14 days from reentering ${ }^{85}$. This was counter to WHO's recommendations which advised that "restricting the movement of people and goods during public health emergencies is ineffective in most situations and may divert resources from other interventions. Furthermore, restrictions may interrupt needed aid and technical support, may disrupt businesses, and may have negative social and economic effects on the affected countries $^{86}$ ". Moreover, the WHO advised that,

Travel measures that significantly interfere with international traffic may only be justified at the beginning of an outbreak, as they may allow countries to gain time, even if only a few days, to rapidly implement effective preparedness measures. Such restrictions must be based on a careful risk assessment, be proportionate to the public health risk, be short in duration, and be reconsidered regularly as the situation evolves ${ }^{87}$.

Yet, the United States did not take sufficient advantage of any potential window of opportunity. Instead, as I have argued elsewhere, "delays in developing a reliable test, plus a limited and faulty domestic supply, as well as restrictions on testing based on travel history, meant that the virus was likely spreading locally undetected for a while 88 ".

The racial and colonial logics influencing COVID-19 law and policymaking by the Trump administration was evident in innumerable ways. First, the President's problematic understanding of the disease as racialized and "foreign," constrained the space initially for consideration of community transmission within the United States. This led to an over reliance on general travel bans as a magical solution to stop the spread of a highly infectious novel disease. In addition, imperial rationales were evident in the administration's decision to initially exclude certain countries from the application of general travel bans. Thus, the administration initially exempted the United Kingdom ${ }^{89}$ from the expanded travel ban that it imposed on the European Schengen area ${ }^{90}$. The Proclamation from the White House which later added the United Kingdom

\footnotetext{
${ }^{85}$ See The White House, Proclamation on Suspension of Entry as Immigrants and Nonimmigrants of Persons who Pose a Risk of Transmitting 2019 Novel Coronavirus (January 31, 2020), https://www.whitehouse.gov/presidentialactions/proclamation-suspension-entry-immigrants-nonimmigrants-personspose-risk-transmitting-2019-novel-coronavirus/. ${ }^{86}$ WHO, COVID-19 Travel Advice, supra note 82. ${ }^{87} \mathrm{Id}$.

${ }^{88}$ Matiangai Sirleaf, COVID-19 and the Racialization of Diseases (Part II), OPINIO JURIS (April 7, 2020), http://opiniojuris.org/2020/04/07/covid-19-symposiumcovid-19-and-the-racialization- of-diseases-part-ii/.

${ }^{89}$ See White House, Proclamation-Suspension of Entry as Immigrants and Nonimmigrants of Certain Additional Persons Who Pose a Risk of Transmitting 2019 Novel Coronavirus (March 11, 2020), https://www.whitehouse. gov/presidential-actions/proclamation-suspension-entry-immigrantsnonimmigrants-certain-additional-persons-pose-risk-transmitting-2019-novelcoronavirus/ (note the United Kingdom does not appear on the order).

${ }^{90}$ See White House, Proclamation on the Suspension of Entry as Immigrants and Nonimmigrants of Certain Additional Persons Who Pose a Risk of Transmitting Coronavirus (March 14, 2020), https://www.whitehouse.gov/presidential-actions/ proclamation-suspension-entry-immigrants-nonimmigrants-certain-additionalpersons-pose-risk-transmitting-coronavirus-2/.
} 
to the ban, notes that the "CDC has determined that the United Kingdom is experiencing widespread, ongoing personto-person transmission of SARS-CoV-2 ${ }^{91}$ ". Yet, this information was readily available to the administration and circumstances in the United Kingdom had not changed materially between the proclamation released on March 11, which excluded the United Kingdom and the one released on March 14, 2020, which included it ${ }^{92}$.

Moreover, the lackadaisical approach to implementing screening measures at airports and the attendant lack of a coherent plan to accommodate the rush to the airports from United States nationals situated abroad who frantically attempted to return home from the newly banned countries all indicate a lack of consideration of the public health risks involved when adopting the additional measures. Cumulatively, the above travel bans, and their haphazard implementation do not support a conclusion that they were primarily aimed at diminishing the risks of spreading COVID-19. Instead, the administration's policies indicate how the racializing of diseases led to public health law and policy decisions that seemingly assumed that the disease is engaged in racialized border control efforts; checking documents and nationalities to determine who to infect next ${ }^{93}$.

\section{CONCLUSION}

The objective of this essay is to render race visible in migration and global public health law and policy. This essay serves as a powerful reminder of how the history of diseases and responses to diseases is linked to colonial and ongoing politics of racial exclusion. The argument developed thus far may be perceived as overly relying on race in ways that downplay other factors. Given the impossibility of severing race from other influences in the world, this essay does not engage in a futile attempt to disprove the relevance of other variables compared to race. There are of course other factors contributing to the migration and global health law policies analyzed in this essay.

For instance, the total number of cases for a disease also influences the imposition of travel bans and other restrictions. Accordingly, over 30 countries have placed broad travel bans on travelers from the United States ${ }^{94}$. Thus, an administration notorious for increasing the racialization of borders in the United States from the "Muslim Ban" ${ }^{95}$ " to the recent expansion of the travel ban to include Burma (Myanmar), Eritrea, Kyrgyzstan, Nigeria, Sudan, and Tanzania ${ }^{96}$,

\footnotetext{
${ }^{91} I d$.

${ }^{92}$ Cf. supra note 89 with 90.

${ }^{93}$ Sirleaf, supra note 88 .

${ }^{94}$ Alexandra Sternlicht, These 33 Countries Have Banned U.S. Travelers, FORBES (July 20, 2020), https://www.forbes.com/sites/alexandrasternlicht/2020/ 07/20/these-33-countries-have-banned-us-travelers/\#4cdf3fe47ea9.

${ }^{95}$ White House, Executive Order Protecting the Nation from Foreign Terrorist Entry into the United States (March 6, 2017), https://www.whitehouse.gov/ presidential-actions/executive-order-protecting-nation-foreign-terrorist-entryunited-states- $2 /$.
}

now has to contend with what it perceives as "shit-hole countries $^{97 "}$ in the Global South imposing travel bans on its residents. The administration must also face the ignominy of its perceived peers in the Global North placing travel bans on Americans, including all 27 countries in the European Union $^{98}$. Additionally, both Canada and Mexico prohibited nonessential travelers from the United States to cross their borders ${ }^{99}$. And, a poll in July of 2020, found that $80 \%$ of Canadian respondents wanted the border to stay closed until at least the end of $2020^{100}$.

The COVID-19 pandemic and the responses to halt its spread have fundamentally altered the world as we know it. Yet, as this essay shows the more things change, the more they stay the same. Although, the COVID-19 pandemic has revived stereotypical colonial imaginations, it also simultaneously challenges racialized hierarchies of diseases. This duality creates an opening to rethink and reshape the relationship between race, migration and global health and opens new possibilities for anti-subordination efforts.

\section{AUTHOR'S NOTE}

This essay illuminates how the racialization of diseases is reflected in historic and ongoing United States' migration law and policy as well as the global health law regime. By demonstrating the close relationship between often separately treated areas, the essay clarifies underlying currents in global health and migration law and policy that stem from fears of the racialized other. Rendering these intersections visible creates avenues for rethinking and reshaping both theory and praxis toward antisubordination efforts.

\section{AUTHOR CONTRIBUTIONS}

The author confirms being the sole contributor of this work and has approved it for publication.

Conflict of Interest: The author declares that the research was conducted in the absence of any commercial or financial relationships that could be construed as a potential conflict of interest.

Copyright (c) 2020 Sirleaf. This is an open-access article distributed under the terms of the Creative Commons Attribution License (CC BY). The use, distribution or reproduction in other forums is permitted, provided the original author(s) and the copyright owner(s) are credited and that the original publication in this journal is cited, in accordance with accepted academic practice. No use, distribution or reproduction is permitted which does not comply with these terms.

\footnotetext{
${ }^{96}$ White House, Proclamation on Improving Enhanced Vetting Capabilities and Processes for Detecting Attempted Entry (January 31, 2020), https:// www.whitehouse.gov/presidential-actions/proclamation-improving-enhancedvetting-capabilities-processes-detecting-attempted-entry/.

${ }^{97}$ See Julie Hirschfeld Davis et al., Trump Alarms Lawmakers With Disparaging Words for Haiti and Africa, N. Y. Times (January 11, 2018) https://www.nytimes. com/2018/01/11/us/politics/trump-shithole-countries.html.

${ }^{98}$ Sternlicht, supra note 94.

${ }^{99} I d$.

${ }^{100}$ Robin Levinson-King, Americans, Go Home: Tension at Canada-US Border, BBC NEws (August 13, 2020), https://www.bbc.com/news/world-us-canada53742684
} 